\title{
Research on the Innovation of League Work in Universities under the Background of Mass Organization Reform
}

\author{
Long Bai ${ }^{1, a}$ \\ ${ }^{1}$ College of Management, Southwest Minzu University, 610041, China \\ ${ }^{a}$ email
}

Keywords: League work, Mass organization reform, Communist Youth League

\begin{abstract}
Strengthening the construction of league work in universities is of great significance to improve the quality of students and build a harmonious campus. In July 2015, General secretary Xi Jinping put forward new requirements for the mass organization reform. Under the new situation, the league work in universities is facing great challenges. This paper gives the challenges and solutions of the league work in universities and provides some references for the relevant researchers.
\end{abstract}

\section{Background of Mass Organization Reform}

$\mathrm{Xi}$ Jinping clearly put forward the profound three essential attributes judgment of mass organizations, which are the political attribute, the advanced attribute and the mass attribute in the Central Party's mass work conference. He is on the three attributes of the inherent logic relation of dialectical analysis, expand and deepen the mass organization which has a China characteristic morphology of the dimension of cognition. Political mass organizations are the endogenous factor. This political nature is not only reflected in the theoretical definition, but also reflected in the practice of real life. From the perspective of the party, the party committees at all levels should be the work of the party and the country overall situation, strengthen and improve the leadership of the working group, to create favorable conditions and provide support for mass organizations to carry out the work. Advanced sex is an important attribute for the mass organization. Advanced mass organizations are mainly embodied in two aspects: first, in the growth orientation, development vision, high mass organization. The trade unions, the Communist Youth League, women's federations and other mass organizations and firmly grasp the theme of the times and strive for the great rejuvenation of the Chinese nation China dream, unite and mobilize by contact with the masses consciousness as the central task, the overall work of the party and the country's service. Mass organizations at the forefront of the times, leading to advanced backward to civilization and progress instead of ignorance behind, consciously practice the socialist core values, to educate and guide the masses to improve the level of political consciousness and moral, is the ruling party, relying on the strength of solid strong support and profound social basis. The mass organization is the direct leadership of the party masses in their own organization, according to the articles of association of independent work, is the basic characteristics of the masses. Mass organizations linked to specific interest groups, such as trade unions on behalf of the interests of workers, youth, women's League ties, safeguard the legitimate rights and interests of women science and technology workers association services. Therefore, it plays a special important role in mobilizing the masses, organizing the masses, publicizing the masses, reflecting the masses' demands, safeguarding the rights and interests of the masses, and standardizing the behavior of the masses.

\section{Challenges of League Work in Universities under the Background of Mass Organization Reform}

Imperfect Organizations of League Work. At present, the League cadres are lack of sense of responsibility and weak sense of cooperation. At present, the lack of sense of responsibility and weak sense of cooperation are common in League Cadres in universities. The reason is mainly from the following aspects. First, the student cadre selection mechanism is not perfect, but the selection of the 
main channel or from the internal members to choose outstanding members of college student cadres is mainly from the internal members of the league, class cadre and other organizations in the University, but because of vicious competition between the internal members so that they often use improper means in the election process, makes a lot of group work ability and Title student leaders. Secondly, the cadres' Utilitarian mentality makes them have a weak sense of responsibility in the process of work. Finally, the incentive and assessment system of league work in universities cannot effectively stimulate the team spirit of cadres, often only entangled in their own gains and losses. With the full implementation of the logistics socialization reform of higher education reform and quality education, the expansion of school and college, in the implementation of flexible schooling system, multi campus and graded English teaching situation, students choose classes due to teaching, learning and classification learning across the campus and the formation of a new informal groups of students. The emergence and existence of the students is weakened as the concept of natural class students of the whole unit, the original class and students' cadres in the ideological and political education, the construction of academic discipline and quality development and exercise effect, difficult to obtain in the new situation, give full play to. At the same time, there are loopholes and breaks in the traditional student organization network system. There is a blank point in the work of colleges and universities, especially in the work of the Communist Youth League.

Inadequate Cadres of League Work. The students' education and management cultivate the quality of students and other aspects of development is facing the following problems. First, the students in the class because there is no fixed group organization, the contact between teachers and students lack of effective bridge and link. It is difficult for teachers to organize teaching activities, arrange teaching tasks, check teaching effects and communicate with teachers and students. The job vacancy and system vulnerabilities, above the new situation on strengthening college students unity of knowledge have a certain impact, the evaluation system of students' quality of the original is one-sided, difficult to objectively reflect the effect of exercise training, and evaluation of the quality of students, outstanding members directly lead to work, party the principle of Ideological and political education work to fully implement the work, the comprehensive quality evaluation of students and members of education evaluation, awards and quality training that authenticity is not fully guaranteed. If things go on like this will lead to problems such as the diaphragm between teaching efficiency is not high, the classroom atmosphere is loose, the teachers and students, directly affects the teaching effect, the impact of the construction of school spirit and study style, is not conducive to "realize the teaching goal. At present, the group activities in universities are monotonous. At present, many colleges and universities in the group work, often initially with a perfunctory attitude in the completion of the work. Only in festivals and anniversaries each copy past mode to carry out activities in the form of group learning activities are monotonous and lack of novelty, makes the students to participate in the enthusiasm of the phenomenon is more prominent. Due to the lack of effective management mechanism and expanding organizations and students of distance and make them in a state of disorder, blind development, to maintain the stability of the campus and promote the communication between teachers and students and expand the comprehensive quality is bad.

Insufficient Propaganda of League Work. College students are talents with modern scientific knowledge. They are representatives of contemporary youth, and will play an important role in the future economic development. The ideological and political leading work of young students is the key and difficult problem in the work of the Communist Youth league. At present, the college group organization has many attempts in the application of new media, but there are still the following problems: one is more fragmented, not systematic; two is the lack of coordination between pre-judgment. Some are mainly in communication and work arrangements, to carry out ideological and political guidance and development services etc. Therefore, insufficiency, shall be equipped with foot, the Propaganda Department of the Communist Youth League's strength, improve and expand the functions of the design, promotion, publicity and innovation, enhance the work of the Communist Youth League especially central brand project, and through the central drive other departments. Let the traditional group organization propaganda department issued a notice, from the original posters, 
out of activities, gather a group of ideas, passion, understand the theory, understand students, understand the design, understand technology, understand the market for students dry, characteristics of the era of unity the image, in accordance with the design of modern communication rules, leading the trend, leading the students to truly achieve the purpose, rather than blindly follow the trend and cater to students. Students' main business or learning, the main time is still in the classroom, our line of sight can not only in the second classroom. This can make university cadres improve themselves, on the other hand can understand students, make clear students attention, interest, to get the students' real identity in thought.

\section{Innovation Directions of League Work in Universities under the Background of Mass Organization Reform}

Reform Organizational Structure of League Work. The grass-roots League organization is under the leadership of the Party committee and Youth League committee. Therefore, the development of the league work should be based on the characteristics of schools and colleges to build organizational structure, so that it is conducive to the smooth development of League organizations. The administration should pay attention to the League organizations, and actively help the League organizations to carry out activities and organizational construction. According to the school characteristics and market demand, schools should carry out professional league activities according to the training methods of professional talents. And strengthen the assessment of the actual effect of all kinds of league work, to promote the group cadres seriously thinking, and constantly create suitable for students' activities, to meet the needs of students. At the same time, we also encourage the excellent students to participate in the activities of the League organization, give full play to the exemplary role of outstanding students, and constantly lead the students to learn and improve their ability. To carry out the league work, we should fully respect the individual ability to play, to provide students with their own platform. All the group organization to respond positively to the school organization's call, actively carry out the work of the league, and for most students, mobilize the enthusiasm of students to continuously improve the group organization execution. Every department in a league organization should have corresponding work, and doing a good job is the basis for the existence of the League organization. In the league work, we should seriously treat each service object. Do routine work planning, grasp the scale of activities, and constantly innovate, look at the overall situation, really do a good job in group work. Under the new situation, it is necessary to further strengthen the construction of League organization in universities. By studying the current situation of the League organization in universities, let us realize the necessity of accelerating the innovation of league work in universities. Therefore, we need to speed up the innovation of College League work model to train qualified successors and builders for the party and socialist cause.

Construct Cadres Team of League Work. League cadres to promote the smooth development of grass-roots work in Colleges and universities, in the cultivation of innovative talents in Colleges and universities have an important guiding role. Universities should attach great importance to the cultivation of League cadres, promote the healthy development of college students and promote the all-round development of college students through League cadres. Is a bridge linking college students' cadres and students, they can promptly convey the instructions of the school, also can reflect the basic needs of students to the school, and can be combined with the actual situation of the implementation of the school decision. Excellent League cadres can not only solve the difficulties and problems in students' daily life and study, but also help to coordinate the relationship between teachers and students, organize various activities effectively, and promote the smooth development of League work. In practice, through the continuous innovation of activities, we can effectively carry out the basic education work of College students. We should pay attention to establish and improve the selection mechanism of League cadres. We should set up a contingent of cadres with high quality, such as sense of responsibility, motivation, and dedication, and be able to help and care for students and unite students. In the student cadre selection process, according to the reasonable selection of the rules and procedures of the electoral process by all supervision, let those excellent, high quality, the 
ability of the students to actively join the group of cadres, for more students to participate in the mission of cadre election provides an important platform. There a group to build innovation after the organization is based on the actual situation of temporary existence, does not involve the registration and collection of data tour and other issues, we must resolutely safeguard the authority of the traditional organizations on this issue. At the same time, we should strengthen the cultivation of innovative ability and working ability of College League cadres, and constantly improve their sense of cooperation and team spirit. Effectively establish a strong group of cadres of University League, and enhance the service function of students.

Update Media Propaganda of League Work. Today's college students, the intelligent mobile phone, notebook computer, iPad, tablet computer is very popular, the wireless network to cover almost every corner of the campus network, always affect the thinking and behavior of college students, micro-blog, WeChat and other new media, has become a part of university life. Therefore, the group workers should make full use of the advantages of the school resources and the advantages of new media, so that the new media in universities become an important platform for the dissemination and construction of the group culture. In the work of the league in universities, to gradually put the health of the network information dissemination to young students, build a comprehensive campus network platform for most young students, the use of new media to implement the work of the league in universities. We actively carry out special education to Party members, Party branch with members, carry out monthly in all members of young people to read a book, see a red film, ten hours of voluntary service activities to achieve advanced typical tree to provide a platform for the exchange and study group organization of student cadres. We should strengthen the innovation of group work in the field of new media, cooperate with all major portals, attract more youth attention and serve the League work. Using the network platform to carry out the league work in universities, can make each student equally participate in the discussion, use the new media, pay attention to the information of the league work at any time and place. At the same time, we can also participate in the interaction, better promote the communication and communication of College League work, and constantly improve the democracy of League work. We should make full use of the new media to strengthen the multi League work, and strengthen the smooth development of the league work in the campus. Whether young people in an era have the correct ideals and beliefs, determines the future and destiny of a country.

\section{Conclusion}

Under the background of the continuous development of education in our country, it also puts forward new and higher requirements for the personnel training in universities. League work plays a very important role in promoting students' growth and practical ability. In the past, there were various problems in league work. Only by innovating can we carry out the work of league work more effectively and efficient.

\section{References}

[1] Kang Xiaoqiang. On Xi Jinping's View of Mass Organizations [J]. Socialism Studies, 2017(1):

[2] Li Rui. Innovation Mode of Work of the League in Universities in the New Situation [J]. The Guide of Science \& Education, 2015(5): 74-75.

[3] Liu Ruijun. The Application and Research of the Project Management Mode in the League Work in Colleges and Universities [J]. Education Teaching Forum, 2017(35): 167-168.

[4] Bei Jinghong. A Research on the Innovation of College Trade Union Work from the Perspective of Mass Organization Reformation: A Case Study in H University [J]. 2016(2): 73-77. 